\title{
The Effect of Consumer Relationship Management on Satisfaction and Loyalty: A Focus on Albanian Tour Operator Business
}

\author{
Arnil Lacej, M.A. \\ Lauder Business School, Vienna \\ arnil.lacej@gmail.com \\ Ermira H. Kalaj, Ph.D. \\ Aleksander Moisiu University, Durres \\ ermirahoxha@uam.edu.al
}

\section{Doi:10.5901/mjss.2015.v6n2s1p635}

\section{Abstract}

This paper examines the influence of Customer Relationship Management on customer satisfaction and customer loyalty in the Albanian Tourism Industry. Despite the fact that CRM positive influence on customer satisfaction is widely accepted as a rule of thumb, very little research has been done to further investigate on such a theory. Hence, the study tries to find out if an effective Customer Relationship Management strategy indeed influences customer satisfaction and loyalty. The empirical research attempts to unveil the relationship between Customer Relationship Management Effectiveness, customer satisfaction and customer loyalty by analyzing five CRM attributes, namely; Organizational commitment, Customer experience, Processdriven approach, Reliability and Technology Orientation. Results show that not all CRM features influence or equally influence customer satisfaction and loyalty. Furthermore, it proves that customer satisfaction is indeed a strong mediator of customer loyalty. Based on the results of the study, only organizational commitment, customer experience, process-driven approach and reliability influence customer satisfaction while only reliability positively influences customer loyalty. The hypotheses are tested using information collected from customers through structural equation model approach. The empirical results of this study have academic and managerial implications since they add to the existing body of knowledge and at the same time help CRM managers in the decision making process.

Keywords: Customer Relationship Management, Tourism Industry, Structural equation model

\section{Introduction}

The story with CRM begins more than a century ago, before the arrival of the supermarket, the shopping malls, and the automobile industry. It was a time when America was made up of small towns and people went to their neighborhood store to buy goods. During this time it was common for the owner and the small staff to recognized the customer by name and know exactly what the customer's preferences and wants are, before they would even mention them. The customer on the other hand, in normal circumstances would remain loyal to the store while making repeated purchases (Gray \& Byun, 2001).

This great customer relationship vanished with the disappearing of town-America as the USA grew, and the population started moving from the farm based communities to much larger urban areas. In the process, the consumer became more mobile hence; supermarkets and large department stores were established so that economies of scale could be achieved through mass marketing.

Even though this situation provided for lower prices, better and more standardized goods in terms of quality, the relationship between the person providing the goods and the customer became nameless and faceless. The face-to-face communication between the seller and the buyer slowly became a story from the past. As a result, customers became fickle, moving very easily from one supplier to the other depending on factors like lower costs or more features for the desired goods.

In the recent years Customer Relationship Management (CRM) has become increasingly known as an important business approach. Its main objective is to return back to the roots of the personal marketing world. The relatively simple concept states that, instead of marketing to a mass of people or firms, it is more effective to market to each customer in a customized and individual way. In order for the company to achieve such a one-to-one approach, information about 
individual customers is used to create offers that would have more chances of being approved from the customer. This process is made easier and simpler due to developments in IT.

According to Eichorn (2004) another factor of success in the implementation of CRM is, gaining employee buy-in and dealing with cultural issues.

There is a lot of controversy going on about the factors that enable CRM to be a successful application. Some researchers say that the most important thing is the organizational culture and structure; on the other side, others emphasize the importance of precisely defining business processes. Above all these arguments, the one that prevails in every research, is the importance that top management involvement has in successfully implementing a CRM system in the company (Imhoff, Loftis, \& Geiger, 2001).

A reason for all this different points of view on what determines the success of the CRM system might be the differing perception of success that different departments in a company have. For example, for the finance department a certain financial target might be considered as success, meanwhile for the marketing department would be how to best meet the needs of the customer and for the sales department increasing the quantity of sales would be the goal.

\section{Literature Review}

So far, there exists a body of knowledge on the topic of CRM in the tourism industry. One of the main studies done in this field is the research performed from Özgener and İraz (2006). In their study, the authors analyze the factors that influence the implementation of customer relationship management (CRM) at small and medium-sized tourism enterprises situated in Cappadocia, Turkey. The study shows that communication-distribution, infrastructure, business dynamics, customer relations and innovation-quality are the main factors affecting CRM. Even though this study brings in new findings on the field of CRM and tourism industry, it only looks at it from the business owners' perspective and it only focuses on the barriers for CRM implementation, omitting the purpose of CRM.

In their research Sofi, Bhat, and Rather (2013) state that improvements in CRM Technology can influence positively customer satisfaction in the tourism industry. This study takes into consideration CRM only as technology and it fails at recognizing other dimensions of CRM.

Sigala (2005) states that in the hospitality industry, ICT's role in CRM strategy implementation has been over stated most of the time because of the myriad of ICT suppliers stressing the importance of ICT. Because of this reason the hospitality business has very often had problems in implementing effective CRM strategies. The misconception stands in the fact that CRM is not a technology problem but rather the contrary; it is a business problem that can benefit from ICT tools to improve its functionality. Sigala (2005) demonstrates that successful CRM implementation in the hospitality business requires the alignment of three different managerial processes, namely: ICT, relationship (internal and external) and knowledge management.

The components that create CRM effectiveness have never been tested, if they actually influence satisfaction and loyalty in the T\&T business, from the customers' perspective.

CRM in the Albanian tourism industry has not been studied extensively. So far, the only study done on the matter has been a research performed from Taga and Gaspari, (2011). Their study focuses on the developments of e-CRM in the Albanian industry. It looks at the ICT moderating effects in CRM implementation. Through a qualitative method, the research determines if from the Tour Operators business owners' perspective e-CRM mediates the growth of customer loyalty.

Tour operators' business owners in Albania state that the main reasons for using CRM strategy in their business sector is improving customer satisfaction levels and at the same time build customer loyalty.

On the other hand the results of Taga and Gaspari (2011) show that the human touch or the human interaction factor is indispensable for acquiring customer satisfaction and loyalty in the tourism industry in Albania. According to the Tour Operator business owners, e-CRM can only support the human factor in achieving this customer satisfaction and loyalty. However, it is supposed to be still too early to analyze e-CRM for its benefits because it is still at its initial development stage.

Even though this study helps in understanding the Tour Operators expectations from CRM and e-CRM, it views CRM only as an ICT function, failing to analyze all the other components of CRM.

\section{The Link between CRME, Customer Satisfaction, and Customer Loyalty}

A considerable body of literature is focused on researching the effects of CRME on customer satisfaction.

CRM strategy and functions supports and fosters the ability of firms to collect information on their customers 
through different interactions that the customers have with the firm. The gathered information further on, helps the firm design and produces customized products or services that suit the customers' individual taste. This process helps in enhancing the perception of costumers towards quality, hence affecting customer satisfaction (Mithas, Krishnan, \& Fornell, 2005).

According to Kaura, Datta and Vyas (2012) there exist at least three reasons why customer relationship management can effect customer satisfaction; such as, CRM support firms in customizing their offerings for each customer, by accumulating information from customer interactions with the firm. Following, CRM applications help firms customize their offers to match the individual tastes of their customers, whereas customized offers improve the perceived quality of products and services from a customer's perspective. Since perceived quality is a determinant of customer satisfaction, it continues to point out that CRM strategies indirectly influence customer satisfaction through their effect on perceived quality.

Srinivasan and Moorman (2005) researched if the investments in CRM influence customer satisfaction. The results of their research showed that if the firm was strategically committed to CRM, effects of the investment would prove to be positive on customer satisfaction. Johnson and Selnes (2004) state that by properly using the customer knowledge that a CRM-based technology brings to the table, it can be possible to provide customized offers to the customers. This should as a result boost the customer satisfaction (pp. 1-17). According to Kaura et al, (2012) improved people, processes and physical aspects of service quality help in increasing customer satisfaction.

Ndubisi and Wah (2005) proved that there are six dimensions of CRM that influence customer satisfaction. Molina, Martín-Consuegra and Esteban (2007) demonstrated that firms that had a strong commitment on customer relationship strategy had higher levels of customer satisfaction. Therefore the hypothesis would be: H1: The Effective application of CRM dimensions positively influences customer satisfaction.

Successful CRM efforts are expected to have as their main outcome high levels of customer loyalty. The researches performed from Abratt and Russell (1999), Farquhar (2004) support the idea that CRM efforts help in establishing stronger bonds with the firm and higher customer loyalty levels .

Additionally, relationship efforts focused on an individual customer influence the customers' loyalty more than when these efforts are directed towards a group of individuals (Palmatier et al, 2006). A perception of an existing personal relationship between the firm and client supported by the right CRM activity builds customer loyalty (Abratt \& Russell, 1999). This is created by properly handling the customer information provided by CRM (Mithas et al, 2005). Moreover, Minghetti (2003) in her study performed on the hospitality industry supports the fact that deep knowledge of customers' needs, behavior, and preferences and its proper management stimulates customer loyalty. Based on the aforementioned information one can logically hypothesize that: $\mathrm{H2}$ : The Effective application of CRM dimensions positively influences customer loyalty.

Prvathy et al (2012) Identify customer satisfaction as the main predictor of customer loyalty. Costumers satisfied from the relationship with the firm are strongly inclined to be loyal to the firm. (Bloemer, Ruyter, \& Peeters, 1998; Licata \& Chakraborty, 2009). According to Leverin and Liljander (2006) among the customers served with a sales-orientation approach the once satisfied with the relationship were more prone to be loyal to the firm. According to Anton (1996) (as cited in, Abdallat \& Emam, n.d., p.1) customer satisfaction results in customer loyalty. Therefore the next hypothesis is: H3: Customer satisfaction positively mediates customer loyalty

\section{Data and Methodology}

The questionnaire developed for this study is divided in four main parts. The first one is concerned with gathering demographic data that are actually not directly relevant to the hypothesis testing, but they can help in discovering unpredicted results. The second pat is concerned with the CRME definition. The third part is meant to test the customer satisfaction while the last part is focused on testing the level of customer loyalty.

The part concerned with gathering demographic information is composed of five questions. Meanwhile the sixth and the seventh are supposed to focus the respondents' attention towards the tour operator of choice so that the evaluation of CRME can be done.

All the questions are close ended format except for the one where the respondent is asked to name the tour operator that he/she mainly uses.

The part concerned with the evaluation of CRME uses as measurement tool a 16-item scale, while the customer satisfaction and loyalty is measured using a three-item scale adopted from Padmavathy, Balaji and Sivakumar, (2012). All the items measuring CRME, customer satisfaction and customer loyalty are based on a five point Likert scale ranging from 1-srongly disagree to 5- strongly agree. 
The items developed to measure CRME in the Tour Operator business sector in Albania are shown in the table 1.

Table 1: Indicators and CRME variables

\begin{tabular}{|c|c|}
\hline Organizational commitment - OC & OC \\
\hline This tour operator regularly uses personal information to provide customized products/services. & (OC 1) \\
\hline Employees of this tour operator often interact with customers to assess service performance. & (OC 2) \\
\hline This tour operator assesses customer satisfaction regularly. & (OC 3) \\
\hline This tour operator carefully evaluates customer-evolving need. & (OC 4) \\
\hline Customer experience - CE & $C E$ \\
\hline This tour operator attends customer complaints promptly. & (CE 1) \\
\hline This tour operator takes genuine interest in customer problems. & (CE 2) \\
\hline This tour operator effectively communicates to customers. & (CE 3) \\
\hline This Tour operator is co-operative. & (CE 4) \\
\hline Process-driven approach - PD & $P D$ \\
\hline This tour operator delivers services at the earliest. & (PD 1) \\
\hline This tour operator designed their service processes to satisfy the customer. & (PD 2) \\
\hline Providing a correct and rapid service is very common for this tour operator. This Tour operator provides & (PD 3) \\
\hline value-added information along with its products/services. & (PD 4) \\
\hline Reliability - REL & REL \\
\hline This tour operator maintains consistent service standards. & (REL 1) \\
\hline This tour operator provides reliable services. & (REL 2) \\
\hline
\end{tabular}

CRME is composed of five variables that are supposed to create an effective CRM. These variables are namely; Organizational commitment; Customer experience; Process-driven approach; Reliability; Technology orientation.

To test the customer satisfaction-CS levels, the following three indicators were adapted in order to match the context in which they were going to be applied. The applied statements are again set up in the form of a five point Likert scale. Bryman (2012) identifies two types of sampling, probability and non-probability sampling.

For this research, the author has decided to use a non-probability sampling, even though the non-probability sampling might have its limitations in generalization compared to the probability one. Financial and time constraints are the reason for choosing this type of sampling. There are three types of non-probability sampling, quota sampling, convenience sampling, snowball sampling.

The authors approached at first students from different universities in Albania. These respondents' answers were collected using a paper-based questionnaire, in which there were included, as an optional personal questions like; Name and e-mail address. The same procedure was followed with other respondents from different fields of life, which were within the reach of the author. Another way of contacting possible respondents was through the pool of local touroperators' customers, this was achieved with the help of the local tour-operator managers.

The second step was developing the online survey. The online survey was developed and spread using "kwiksurveys.com" online platform. The link developed was then spread through e-mail and Facebook to all the contacts that the author had already collected using the paper-based questionnaire, and asked them to forward the link to their friends or acquaintances. The questionnaire was also sent to the database of Albanian contacts that the author already had.

Concerning the testing of the data-gathering tool, to establish the internal reliability of the constructs, Crombach's a was calculated, a correlation test was made available and fit test was applied. Meanwhile the relationship testing between the independent and dependent variable was made possible by employing such statistical tools as a linear regression and a more appropriate tool called Statistical Equation Modeling (SEM). The SEM model was build using the STATA GUI SEM builder.

\section{Empirical Results}

The first step in testing the hypotheses is establishing the construct reliability of the questionnaire used for this purpose. Reliability is concerned with testing the consistency of a concept measure. The factors involved in assessing reliability are internal reliability and inter-observer consistency. According to Bryman (2012), the concern about causality is normally reflected in the preoccupation of the research with internal validity. Internal reliability is a criterion of good quantitative research because this kind of reliability test frequently shows the extent to which there is confidence in the researcher's 
causal inferences.

Cronbach's alpha is a very common test used for establishing internal reliability. It calculates the average of all possible split-half reliability coefficients. In normal circumstances an alpha coefficient will be between 1 (perfect internal reliability) and 0 (no internal reliability). The level of 0.80 is typically referred to as an acceptable level of internal reliability (Bryman, 2012).

In the case of this study, the levels of alpha are well above the 0.80 typically accepted level, demonstrating a high level of internal consistency. As shown in the table above the alpha levels for the different indicators are $\mathrm{OC}=0.92$, $\mathrm{CE}=0.91, \mathrm{PD}=0.90, \mathrm{REL}=0.91, \mathrm{TO}=0.93$, while the average alpha coefficient is greater than 0.93 , fully supporting the reliability of the construct.

The item-test correlation is the Pearson correlation coefficient, which is calculated for pairs of scores. Test developers striving to select items for a test that have a high correlation to the total score normally use this kind of test, this way they can ensure that the test is internally consistent. The item-test correlation is sometimes referred to as an index of item validity because it tries to show how well the item-measures the concept. The term is synonymous with internal consistency or reliability. The higher it is the more consistent and valid the construct is (Salkind, 2010).

The item-test correlations normally should be roughly the same for all items. Item-test correlations sometimes are not adequate to detect items that fit poorly because of the scale distortion. Therefore, item-rest correlations should be considered (Nunnally \& Bernstein, 1994). SEM is used to analyze the nature and the extent or magnitude of hypothesized dependence and relationships of the variables and at the same time it can help assess the direct or indirect relationships of the variables included in the hypothesis (Reisinger \& Mavondo, 2006).

SEM is normally used to evaluate how well a developed conceptual model composed of observed multiple indicators and hypothetical constructs can explain the collected data (Yoon \& Uysal, 2005).

Table 2: Crombach's a test

\begin{tabular}{ccccc}
\hline Variable & Item-test correlation & Item-rest correlation & Average inter-item correlation & Alpha \\
OC & 0.8804 & 0.8057 & 0.7555 & 0.9251 \\
CE & 0.9205 & 0.8660 & 0.7255 & 0.9136 \\
PD & 0.9406 & 0.9015 & 0.7080 & 0.9065 \\
REL & 0.9069 & 0.8478 & 0.7346 & 0.9172 \\
TO & 0.8977 & 0.7204 & 0.7945 & 0.9392 \\
Test to scale & & & 0.7436 & $\mathbf{0 . 9 3 5 5}$ \\
\hline
\end{tabular}

Table 3: Goodness of fit analysis

\begin{tabular}{lcc}
\hline Fit statistic & Value & Description \\
Likelihood ratio & & Model vs. saturated \\
Chi2_ms (98) & 353.645 & \\
p>chi2 & 0.000 & Baseline vs. saturated \\
Chi2_bs (120) & 3893.913 & \\
& & Root mean squared \\
$\begin{array}{l}\text { Population error } \\
\text { RMSEA }\end{array}$ & 0.099 & \\
$90 \%$ Cl, lower bound & 0.088 & Probability RMSEA< $<0.05$ \\
Upper bound & 0.110 & \\
P close & 0.000 & Akaike info criterion \\
& & Bayesian info criterion \\
Information criteria & 10224.768 & \\
AIC & 10418.276 & Comparison fit index \\
BIC & & Tucker-Lewis index \\
Baseline comparison & 0.931 & \\
CFI & 0.917 & Standardized root mean residuals \\
TLI & & Coefficient of determination \\
Size of residuals & 0.039 &
\end{tabular}


According to Kline (2005) SEM is specifically used for the analysis of measures with strong psychometric characteristics. For analyzing latent variables such as satisfaction or loyalty SEM normally uses hypothetical-constructs or factors that are assumed as explanatory variables reflecting a variable that is not directly observable. In the case of this research, the statements in the questionnaire are used as indicators for measuring latent variables such as satisfaction and loyalty.

The SEM procedure was chosen as the most appropriate tool for the measurement and testing of the proposed causal relationships between the constructs used to determine the unobservable variables tested in this study based on previews studies on similar maters.

The Likelihood ratio shows that the model fits within acceptable parameters because the model versus saturated chi2 as well as the baseline vs. saturated badness of fit can be rejected at $5 \%$ level since both $p>c h i 2=0.000$. The Root Mean Square Error of Approximation (RMSEA) is another test to check the fitness of the model. This scale is considered as a badness-of-fit index where a value of zero indicates the best fit. Nevertheless, a value zero is not realistic. Meanwhile, RMSEA should be less than one so that the model is considered fit (Kline, 2005). In our case RMSEA $=0.099<0.1$ slightly below the maximum acceptable value. Information criteria AIC and BIC normally serve to compare different models, since we do not have other models to compare this indexes are not important.

The baseline comparison indexes for testing the goodness of fit for the hypothesized model are calculated. The comparative fit index (CFI) was 0.932 while the Tucket-Lewis index (TLI) otherwise called the non-normed fit index was 0.917, which exceeds the standards recommended by Baumgartner and Homburg (1996) and as well gets very close to the value one.

The next two indexes calculated are the standardized root mean squared residual (SRMR) and the coefficient of determination (CD). SRMR of "0" corresponds to a perfect fit meanwhile a SRMR value lower than 0.08 shows that the model has a good fit. For this research SRMR $=0.039$ which means that the model has a good fit. CD is like an R2 for the whole model. Hence, a value close to "1" indicates a good fit. For this research $C D=0.994$ which means that the model has a good fit.

Once the model is tested, it is time to test the hypothesis using SEM graphical interpretation.

Figure 1: Structural equation model testing the relationship between CRME dimensions and CS, CL

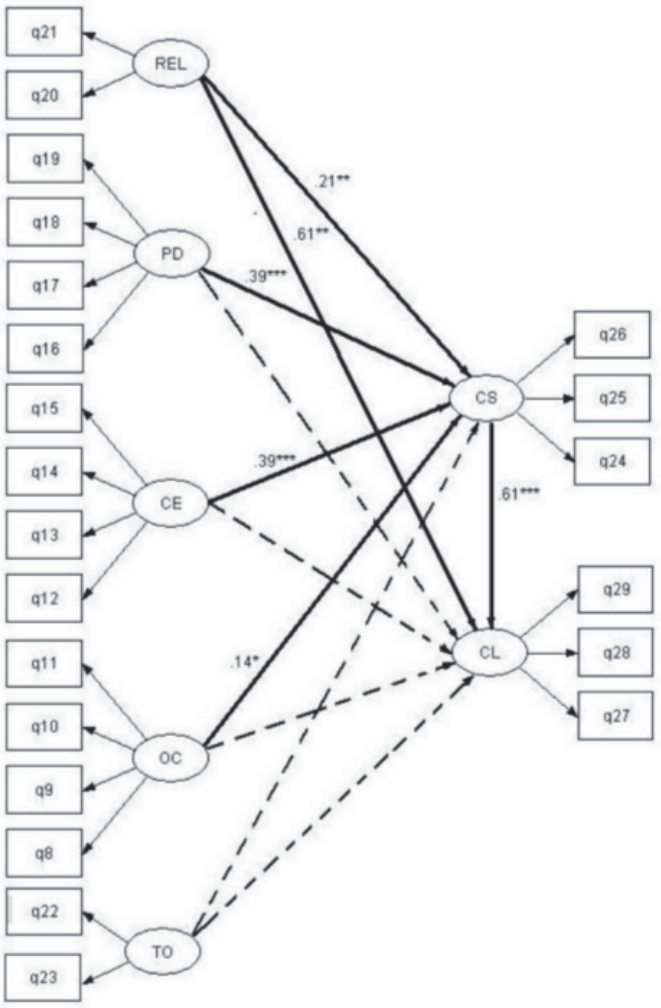


The SEM model shows that REL mediates CS with a coefficient of 0.21 and statistical significance of $p<0.01$ while the mediation onto $C L$ is $R E L=0.61$ and $p<0.01$. PD positively mediates $C S$ with $\beta=0.39$ and $p<0.001$, while its influence on $C L$ is not statistically significant. CE positively mediates only $C S$ with $\beta=0.39$ and $p<0.01$. OC positively mediates $C S$ with $\beta=0.14$ and statistical significance of $p<0.05$, while its influence on $C L$ is not statistically significant. On the other hand, TO influence is statistically significant neither on CS nor on CL. Finally we can see that CS positively mediates CL with $\beta=0.61$ and statistical significance of $p<0.001$.

\section{Concluding Remarks}

Findings of this study have significant implications for the managers of Tour Operators in Albania. This study helps managers of Tour Operators in Albania understand the CRME dimensions that positively affect customer satisfaction and customer loyalty.

In this study, effective CRM is defined as a function of five dimensions. These five dimensions are namely, organizational commitment, customer experience, process-driven approach, reliability and technology orientation.

The findings of this study show that an effective customer relationship management positively affects customer response behaviors namely, customer satisfaction and customer loyalty.

On the other hand, it also shows that customer satisfaction operates as a strong positive mediator between CRME and customer loyalty.

Another conclusion from the results of this study is that out of the five dimensions of CRME only organizational commitment, customer experience, process-driven approach and reliability strongly and positively affect customer satisfaction.

Whilst the study shows that, only the reliability dimension positively affects customer loyalty.

Meanwhile technology orientation is not a CRME dimension that positively affects neither customer satisfaction nor customer loyalty.

An interesting fact is that according to the information provided in this research, females consider "customer experience" as the only CRME dimension that positively mediates customer satisfaction, while customer loyalty is positively affected from reliability and costumer experience. For males, customer experience and process-driven approach effect customer satisfaction while only organizational commitment and process-driven approach positively influence customer loyalty.

Organizational commitment" shows that customers of tour operator businesses in Albania are positively affected in terms of satisfaction, by the efforts of employees to offer the desired levels of performance. It also shows that values, attitudes and beliefs of the tour operator in terms of CRM efforts are pivotal in establishing positive and mutually benefiting relations with the customer.

The second dimension "customer experience" shows to what extent tour operators in Albania adapt to CRM efforts by immediately taking care of customer complaints through a proactive customer support. The "process-driven approach" enables the tour operators to fulfill customer requests with the necessary speed and intelligence, contributing to customer satisfaction.

The "reliability" dimension shows that the tour operators in Albania, by delivering a consistent service quality as promised, positively affect customer satisfaction and loyalty. This shows that the reliability dimension of CRM is crucial in achieving competitive advantages such as a higher customer value.

The last dimension "technological orientation" shows the level of technological novelty that the tour operator uses in delivering the service, but this study indicates that in the tour operator business of Albania such a dimension does not affect customer satisfaction and loyalty.

It is worth stressing out the fact that only reliability could significantly influence customer loyalty.

\section{References}

Abdallat, M. M., \& Emam, H. S. (n.d.). Customer Satisfaction. Department of Tourism and Hospitality, Faculty of Tourism and Archeology King Saud University.

Abratt, R., \& Russell, J. (1999). Relationship marketing in private banking in South Africa. International Journal of Bank Marketing, 17(1), 5-19.

Baumgartner, H., \& Homburg, C. (1996). Applications of structural equation modeling in marketing and consumer research: A review. International Journal of Research in Marketing, 13, 139-161.

Bloemer, J., Ruyter, K. D., \& Peeters, P. (1998). Investigating drivers of bank loyalty: the complex relationship between image, service quality and satisfaction. International Journal of Bank Marketing, 16(6/7), 276-286. 
Bryman, A. (2012). Social research methods. Oxford: Oxford University Press.

Eichorn, F. L. (2004). Internal Customer Relationship Management (IntCRM) A Framework for Achieving Customer Relationship Management from the Inside Out. Problems and Perspectives in Management, 1(1), 154-177.

Gray, P., \& Byun, J. (2001). Customer Relationship management. Irvine, CA: University of California.

Hendricks, K. B., Singhal, V. R., \& Stratman, J. K. (2006). The impact of enterprise systems on corporate performance: A study of ERP, SCM, and CRM system implementations. Journal of Operations Management, 25(1), 65-82.

Hoe, S. J. (2008). Issues and procedures in adopting structural equation modeling technique. Journal of Applied Quantitative Methods, 3(1), 76-83.

Imhoff, C., Loftis, L., \& Geiger, J. G. (2001). Building the customer-centric enterprise: Data warehousing techniques for supporting customer relationship management. New York, NY: Wiley.Indian Travel and Tourism Industry. (n.d.). Travel Tourism \& Hospitality - Industry

Kaura, V., Datta , S., \& Vyas, V. (2012). Impact of Service Quality on Satisfaction and Loyalty: Case of Two Public Sector Banks. The XIMB Journal Of Management, 9(2), 65-76.

Kline, R. B. (2005). Principles and practice of structural equation modeling (3rd ed.). New York, NY: Guilford Press.

Kotler, P., Bowen, J., \& Makens, J. C. (1999). Marketing for hospitality and tourism. London, Great Britain: Pearson Prentice Hall.

Kruja, A. (2012). The impact on tourism sector development in the Albanian economy.Economia. Seria management, 15(1), 205-218.

Kruja, D., \& Gjyrezi, A. (2011). The special interest tourism development and the small regions. Turizam, 15(2), 77-89.

Licata, J. W., \& Chakraborty, G. (2009). The effects of stake, satisfaction, and switching on true loyalty: a financial services study. International Journal of Bank Marketing, 27(4), 252-269.

Licata, J. W., \& Chakraborty, G. (2009). The effects of stake, satisfaction, and switching on true loyalty: a financial services study. International Journal of Bank Marketing, 27(4), 252-269.

Mackoy, R. D., \& Spreng, R. A. (1996). An empirical examination of a model of perceived service quality and satisfaction. Journal of Retailing, 72(2), 201-214.

Matias, A., Nijkamp, P., \& Sarmento, M. (2011). Tourism Economics. Dordrecht: Springer.

Minghetti, V. (2003). Building Customer Value in the Hospitality Industry: Towards the Definition of a Customer-Centric Information System. Information Technology \& Tourism, 6, 141-152.

Mithas, S., Krishnan, M. S., \& Fornell, C. (2005). Why Do Customer Relationship Management Applications Affect Customer Satisfaction? Journal of Marketing, 69(4), 201-9.

Molina, A., Martín-Consuegra, D., \& Esteban, Á. (2007). Relational benefits and customer satisfaction in retail banking. International Journal of Bank Marketing, 25(4), 253-271.

Ndubisi, N. O., \& Wah, C. K. (2005). Factorial and discriminant analyses of the underpinnings of relationship marketing and customer satisfaction. International Journal of Bank Marketing, 23(7), 542-557.

Nunnally, J. C., \& Bernstein, I. H. (1994). Psychometric theory. New York: McGraw-Hill.

Özgener, Ş., \& İraz, R. (2006). Customer relationship management in small-medium enterprises: The case of Turkish tourism industry. Tourism Management, 27, 1356-1363.

Padmavathy, C., Balaji, M. S., \& Sivakumar, V. J. (2012). Measuring effectiveness of customer relationship management in Indian retail banks. International Journal of Bank Marketing, 30(4), 246-266. Retrieved from www.emeraldinsight.com/0265-2323.htm

Reisinger, Y., \& Mavondo, F. (2006). Structural equation modelling: critical issues and new developments. Journal of Travel \& Tourism Marketing, 21(4), 41-71.

Salkind, N. J. (2010). Encyclopedia of research design. Thousand Oaks, Calif: Sage.

Sigala, M. (2005). Integrating customer relationship management in hotel operations: managerial and operational implications. International Journal of Hospitality Management, 24, 391-413.

Sofi , S. A., Bhat, S. M., \& Rather, J. A. (2013). Customer Relationship Management and Tourism Industry, Study of Correlation among Different Elements of CRM and Perceptual Differences of Domestic and Outside Tourists. International Journal of Applied Research \& Studies, 2(3), 1-11.

Srinivasan, R., \& Moorman, C. (2005). Strategic Firm Commitments and Rewards for Customer Relationship Management in Online Retailing. Journal of Marketing, 69(4), 193-200.

Taga, H., \& Gaspari, A. (2011). Implementation of Customer Relationship Management in Albania Travel Industry: Its overall impact on performance. Journal of Marketing and Management, 2(1), 50-64.

Xu, Y., Yen, D. C., Lin, B., \& Chou, D. C. (2002). Adopting customer relationship management technology. Industrial Management and Data Systems, 102, 442-452.

Yoon, Y., \& Uysal, M. (2005). An examination of the effects of motivation and satisfaction on destination loyalty: a structural model. Tourism Management, 26, 45-56. 